\title{
Life satisfaction and its contributors among noninstitutionalized older people in Tabriz, Islamic Republic of Iran
}

Akbar Zeinalhajlou, ${ }^{1}$ Mahasti Alizadeh, ${ }^{2}$ Mohammad Sahebihagh, ${ }^{3}$ Asghar Mohammadpoorasl ${ }^{3}$ and Hossein Matlabi ${ }^{4}$

${ }^{1}$ Ageing Research Institute; ${ }^{2}$ Social Determinants of Health Research Centre; ${ }^{3}$ Health Services Management Research Centre; ${ }^{4}$ Department of Health Education and Promotion, Tabriz University of Medical Sciences, Tabriz, Islamic Republic of Iran (Correspondence to: Hossein Matlabi: hmı349@ gmail.com).

\begin{abstract}
Background: With the rising growth of the older population, the well-being of older people is an important objective for both economic and health policy.

Aims: This study investigates levels of life satisfaction among older people living at home and the factors that influence it. Method: Applying probability proportional to size, a cross-sectional survey was conducted of 1067 older people living in Tabriz, Islamic Republic of Iran. The Satisfaction with Life Scale and the Multidimensional Scale of Perceived Social Support questionnaires were administered. The data were analysed using chi-squared tests and logistic regression.

Results: More than half of the participants were dissatisfied with their lives. Female, educated, and active older people reported greater satisfaction than others.

Conclusion: The significant positive effects of perceived social support and physical activity rate indicated that social interaction may be as vital as physical activity for the well-being of older people, and that these qualities should be actively promoted among older people in the Islamic Republic of Iran.
\end{abstract}

Keywords: life satisfaction, social support, elderly, health policy, Iran

Citation: Zeinalhajlou A; Alizadeh M; Sahebihagh M; Mohammadpoorasl A; Matlabi H. Life satisfaction and its contributors among noninstitutionalized older people in Tabriz, Islamic Republic of Iran. East Mediterr Health J. East Mediterr Health J. 2020(4);410-416. https://doi.org/10.26719/ emhj.19.037

Received: 04/04/17; accepted: 01/02/18

Copyright (C) World Health Organization (WHO) 2020. Open Access. Some rights reserved. This work is available under the CC BY-NC-SA 3.0 IGO license (https://creativecommons.org/licenses/by-nc-sa/3.o/igo).

\section{Introduction}

The spread of healthy lifestyles, public health measures and health care over the past century have increased life expectancy (1). Currently, the world population is rapidly ageing and facing an unprecedented situation. It is expected that during the next few decades the population aged 60 years or older in low and middle-income countries will grow at a rate several times faster than the equivalent rate in the developed countries $(2,3)$.

According to the 1996 census, about $6.6 \%$ of the Iranian population was aged 60 or more years; by 2011 the share had increased to $8.2 \%$ (4). Comparisons with other countries show that the Islamic Republic of Iran will be among those with the highest rate of ageing and that over the next 3 decades the population pyramid will be inverted $(5,6)$. The changing demographic structure has created new challenges to improving the well-being of individuals in different age groups. Moreover, with increased longevity and the ageing population, paying attention to older people as a vulnerable social group becomes inevitable. Some of the older people live with a sense of satisfaction and stoical realism in the last years of their lives while others find their decreased abilities and lack of social importance unpleasant (7-11).

Life satisfaction is directly related to social vitality and is one of the effective variables and important indices for explaining an older person's mental health status. People who are more satisfied with life have better physical and mental health than those who are less satisfied (12). People who are satisfied with their lives have more effective and appropriate coping styles, experience deep positive emotions and feelings and have better health. Dissatisfaction with life is correlated with poor health status, depression symptoms, personality problems, inadequate health behaviours and poor social status. This theoretical framework suggests that engagement with the contributors is an important component of successful ageing (13-15).

Over the last 4 decades, the Islamic Republic of Iran has been experiencing rapid sociodemographic and economic changes. Data from population censuses show that rapid urbanization, new patterns of internal migration, declining fertility, the current youth bulge, an upcoming aged population, and the growing number of female-headed households are some of the main population issues to have emerged due to broad socioeconomic changes. The proportion of men and women aged 65 years and over living with their children has decreased (16). Therefore, new research reassessing the well-being challenges for older people is particularly important for understanding the general role that factors such as age, sex, level of education, place of birth, marital status, physical and mental health and family structures play in shaping life satisfaction in rapidly ageing societies. In this study, we aimed to investigate life satisfaction and 
its influencing factors among older Iranian people.

\section{Methods}

\section{Design}

The study sampled a representative cross-section of people aged $\geq 60$ years living in their own homes in Tabriz, Islamic Republic of Iran.

\section{Participants and sampling}

According to data from the Statistical Center of Iran, the population of interest totalled 146312 in 2011 (4). Individuals aged $\geq 60$ years were included in the study. Based on Cochran's sample size formula, and considering prevalence of life dissatisfaction $=0.5, \mathrm{~d}=0.03$ and significance level $=0.95$; sample size was estimated at 1060 . We recruited 1067 individuals in our sample, 514 males and 553 females.

We used "probability proportional to size", a sampling procedure under which the probability of a unit being selected is proportional to the size of the ultimate unit, giving larger clusters or blocks a greater probability of being selected and smaller clusters or blocks a lower probability (17). In the first stage, and in order to ensure that all units in the population had the same probability of selection irrespective of the size of the cluster, 107 blocks were selected out of 8531 urban blocks in Tabriz.

After calculating the sampling interval by dividing the total population by the number of blocks, the random starting point (first block) was selected in a range between 1 and the sampling interval using a random number table. The succeeding blocks were determined utilizing a randomized systematic sampling process. At the next stage, 10 eligible older people were randomly nominated from each block. People were considered ineligible if they had multiple chronic difficulties or severe cognitive impairment, or were too frail to undertake the survey.

\section{Measures}

The questionnaire included both demographic information and the Farsi version of the Satisfaction with Life Scale standard questionnaire (13). The original scale was designed in 1958 and has been used in many intercultural studies with high reliability and validity. The scale contains 5 items which are evaluated using a 5-point Likert scale from "always dissatisfied" (score 5) to "very satisfied" (score 25). The validity and reliability of the Farsi version of the questionnaire have been evaluated in other studies $(18,19)$.

The perceived social support was assessed using the Multidimensional Scale of Perceived Social Support (20). This tool was developed in 1988 for evaluating the perceived social support provided by relatives, friends and other individuals important in the person's life. The questionnaire has 2 items which are scored using a 5-point Likert scale from "strongly disagree" to "strongly agree" $(20,21)$. The Iranian version of this tool has been used in a domestic study among older people (22). The questionnaires were evaluated among 45 eligible participants in a pilot carried out before our study. The reliability of the final drafts was accepted using Cronbach's alpha (Satisfaction with Life Scale: $\alpha=0.71$ and Multidimensional Scale of Perceived Social Support: $\alpha=$ 0.83).

\section{Data collection and procedures}

Since the ability of the participants to complete all of the questionnaires was uncertain, a preliminary pilot study was conducted; the results showed that older people were rather weak in completing the questionnaires by themselves. Among those willing to participate in the study, data collection was conducted by trained interviewers through face-to-face interviews. The place where the interviews were conducted was determined in accordance with the convenience and proclivity of the participants. We performed the majority of interviews in a quiet room in the homes of the participants. Each interview lasted 25-35 minutes. If a potential participant was not available at the relevant address, a replacement was selected from the next household on the right.

For the data analysis, descriptive, inferential statistics, chi-squared tests and logistic regression were used. In order to make the appropriate comparisons, the 5 possible responses were dichotomized into "satisfied" or "dissatisfied".

\section{Ethical standards}

Informed consent was obtained from all the people who participated in the study. All procedures performed in the study were in accordance with the ethical standards of the Ethics Committee of Tabriz University of Medical Sciences (number: 1395.1148).

\section{Results}

The mean age of the participants was 70.19 [standard deviation (SD) 8.2] years [males 71.25 (SD 8.26), females 69.20 (SD 8.05) years]. Table 1 compares the level of life satisfaction scores and sociodemographic variables. Male:female ratio was 0.929. In terms of marital status, the most common was "married" and the least common "never married" ( $\mathrm{n}=7)$. Around $54 \%$ were illiterate, with a strong difference between the sexes, men $37.4 \%$, women $70.2 \%$. More than half of the respondents were born in rural areas and had migrated to Tabriz. In terms of family type, $619(58 \%)$ were living in extended families (with > 1 marriage represented).

The descriptive statistics showed that the mean score for life satisfaction was 14.14 (SD 4.12), with the most prevalent category being "dissatisfied".

Evaluating the simultaneous effect of independent variables on life satisfaction using logistic regression showed that the impact of sex, education, perceived social support and daily walking were statistically significant at the $5 \%$ level (Table 2). Assuming other model variables as constant, being female increases the probability of life satisfaction 1.42 times. A higher level of education also had a significant effect on the likelihood of satisfaction with life. Having received elementary, secondary or academic 


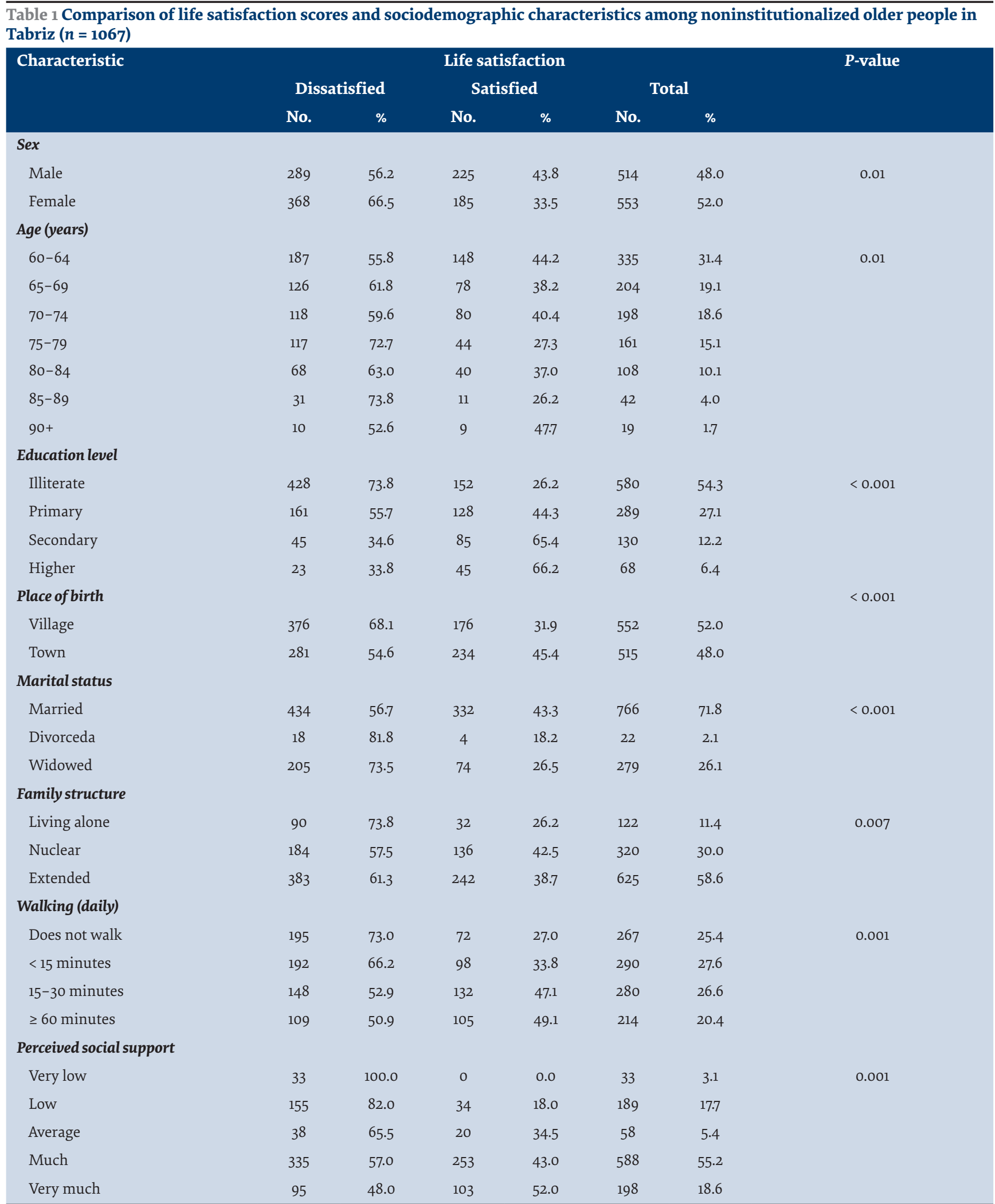

${ }^{a}$ This includes 7 people who were never married. Since the numbers were so low, the 2 groups were merged

education compared with being illiterate increased the odds of satisfaction with life 1.82, 3.84 and 2.87 times respectively. Walking was also associated with the increased chance of satisfaction with life compared to no walking: daily walking of $\geq 15$ minutes had a statistically significant effect on satisfaction with life compared to no walking $(P=0.004)$. According to the regression results, perceived social support also had a significant positive effect on satisfaction with life. Assuming that other model variables were constant, an increase of 1 unit in perceived social support increased the chance of satisfaction with life 1.06 times. 


\begin{tabular}{|c|c|c|c|c|c|c|c|}
\hline \multirow[t]{2}{*}{ Characteristic } & \multicolumn{2}{|c|}{ Dissatisfied } & \multicolumn{2}{|c|}{ Satisfied } & \multirow[t]{2}{*}{ OR } & \multirow[t]{2}{*}{$95 \% \mathrm{CI}$} & \multirow[t]{2}{*}{ P-value } \\
\hline & No. & $\%$ & No. & $\%$ & & & \\
\hline \multicolumn{8}{|l|}{ Age (years) } \\
\hline $60-64$ & 187 & 55.8 & 148 & 44.2 & 1.02 & $1.00-1.04$ & 0.142 \\
\hline $65-69$ & 126 & 61.8 & 78 & 38.2 & & & \\
\hline $70-74$ & 118 & 59.6 & 80 & 40.4 & & & \\
\hline $75-79$ & 117 & 72.7 & 44 & 27.3 & & & \\
\hline $80-84$ & 68 & 63.0 & 40 & 37.0 & & & \\
\hline $85-89$ & 31 & 73.8 & 11 & 26.2 & & & \\
\hline $90+$ & 10 & 52.6 & 9 & 47.7 & & & \\
\hline \multicolumn{8}{|c|}{ Perceived social support } \\
\hline Very low & 33 & 100.0 & 0 & 0.0 & 1.06 & $1.04-1.08$ & $<0.001$ \\
\hline Low & 155 & 82.0 & 34 & 18.0 & & & \\
\hline Average & 38 & 65.5 & 20 & 34.5 & & & \\
\hline Much & 335 & 57.0 & 253 & 43.0 & & & \\
\hline Very much & 95 & 48.0 & 103 & 52.0 & & & \\
\hline \multicolumn{8}{|l|}{ Sex } \\
\hline Male & 289 & 56.2 & 225 & 43.8 & 1.00 & & \\
\hline Female & 368 & 66.5 & 185 & 33.5 & 1.42 & $1.01-2.00$ & 0.047 \\
\hline \multicolumn{8}{|l|}{ Place of birth } \\
\hline Village & 376 & 68.1 & 176 & 31.9 & 1.00 & & \\
\hline Town & 281 & 54.6 & 234 & 45.4 & 1.12 & $0.83-1.50$ & 0.455 \\
\hline \multicolumn{8}{|l|}{ Family structure } \\
\hline Living alone & 90 & 73.8 & 32 & 26.2 & 1.00 & $0.44-1.55$ & 0.552 \\
\hline Nuclear & 184 & 57.5 & 136 & 42.5 & 0.83 & $0.43-1.33$ & 0.338 \\
\hline Extended & 383 & 61.3 & 242 & 38.7 & 0.76 & & \\
\hline \multicolumn{8}{|l|}{ Marital status } \\
\hline Divorceda & 18 & 81.8 & 4 & 18.2 & 1.00 & & \\
\hline Widowed & 205 & 73.5 & 74 & 26.5 & 2.04 & $0.55-7.61$ & 0.287 \\
\hline Married & 434 & 56.7 & 332 & $43 \cdot 3$ & 2.98 & $0.79-11.19$ & 0.106 \\
\hline \multicolumn{8}{|l|}{ Education level } \\
\hline Illiterate & 428 & 73.8 & 152 & 26.2 & 1.00 & & \\
\hline Primary & 161 & 55.7 & 128 & 44.3 & 1.82 & $1.29-2.55$ & 0.001 \\
\hline Secondary & 45 & 34.6 & 85 & 65.4 & 3.84 & $2.38-6.18$ & $<0.001$ \\
\hline Higher & 23 & 33.8 & 45 & 66.2 & 2.87 & $1.56-5.28$ & 0.001 \\
\hline \multicolumn{8}{|l|}{ Walking (daily) } \\
\hline Does not walk & 195 & 73.0 & 72 & 27.0 & 1.00 & & \\
\hline$<15$ minutes & 192 & 66.2 & 98 & 33.8 & 1.30 & $0.88-1.93$ & 0.190 \\
\hline $15-30$ minutes & 148 & 52.9 & 132 & 47.1 & 1.82 & $1.21-2.74$ & 0.004 \\
\hline$\geq 60$ minutes & 109 & 50.9 & 105 & 49.1 & 1.91 & $1.22-2.99$ & 0.004 \\
\hline
\end{tabular}

$\mathrm{OR}=$ odds ratio; $\mathrm{CI}=$ confidence interval.

${ }^{a}$ This includes 7 people who were never married. Since the numbers were so low, the 2 groups were merged.

\section{Discussion}

An understanding of the many determinants of quality of life can serve a number of purposes. One is to identify the most important contributors to quality of life so that they can be targeted for programmes and interventions. Another is to provide a descriptive context for understanding how to appropriately measure quality of life within a particular study. For example, knowing the range and level of education, literacy, medical problems and living circumstances in a particular sample can aid the selection of an appropriate conceptual and measurement approach, e.g. whether the focus should be on lower 
versus higher levels of functioning, or what methods of data collection are optimal. Finally, scores on such determinants can be useful covariates in studies attempting to explain quality of life outcomes, facilitating the isolation of the unique influence of the independent variables of primary interest (23).

Our findings showed significant relationships between satisfaction with life and sex, perceived social support, level of education and daily walking. These findings are consistent with those reported by Borg et al. among older people in Sweden (24) and by Beygzadeh et al. among older people in Shiraz (25).

Old age is the retirement period, which means not only loss of job but also exclusion from social interactions in the workplace (26). Furthermore, the modernization and industrialization of societies is accompanied by changes in the workforce and in family structures that tend to isolate older people, who are increasingly exposed to feelings of loneliness and rejection and psychological risks (27). A reduction in social interactions results in constricted social networks and, consequently, reduced perceived social support. Loneliness can be considered the result of reduced perceived social support. Previous research has demonstrated a significant inverse relationship between loneliness and satisfaction with life (28). Our findings on the significant positive effect of perceived social support and satisfaction with life are consistent with those reported by Adams et al. (29) and
Tamannayeefar et al. (30). In another study, satisfaction with friends showed a significant correlation with life satisfaction among Swedish older people (31). Moreover, the significant positive relationship we found between level of education and life satisfaction replicates the findings of Ho et al. in a study among older people in Hong Kong (32). They also found a significant relationship between physical status and life satisfaction, as did we in Tabriz.

Our study had some limitations. The participants were selected from a group of relatively healthy and younger older people. Although our results were unequivocally positive, the findings may not be representative of the Iranian population as a whole since our sample was selected only among a limited geographical, cultural and religious setting.

\section{Conclusion}

Given the results of the present study, particularly the significantly low satisfaction with life among older women and the strong influence of the perceived social network in generating satisfaction with life, the current perspectives may be reconciled to identify the specific mechanisms that govern the apparent increase in associational involvement with age among older adults. As an example, opening up educational institutions may address the lack of a social network since our research identified this factor as important in life satisfaction.

\section{Acknowledgements}

We are most grateful for the assistance given by the facilitators and participants, and also the Deputy of Tabriz University of Medical Sciences for research and technology. Professor Tony Warnes of the University of Sheffield kindly provided advice on the English expression in the paper.

Funding: Funding for this study was provided by the Social Determinants of Health Research Centre, Tabriz University of Medical Sciences.

Competing interests: None declared.

\section{Niveau de satisfaction dans la vie et facteurs contributifs chez les personnes âgées non institutionnalisées résidant à Tabriz (République islamique d'Iran) \\ Résumé}

Contexte : Compte tenu de l'augmentation croissante de la population âgée, le bien - être de cette tranche d'âge constitue un objectif important pour les politiques économique et sanitaire.

Objectifs : La présente étude portait sur les niveaux de satisfaction à l'égard de la vie chez les personnes âgées vivant à domicile et les facteurs qui l'influencent.

Méthode : En appliquant une probabilité proportionnelle à la taille, une étude transversale a été menée auprès de 1067 personnes âgées résidant à Tabriz. Les questionnaires correspondant à l'Échelle de satisfaction dans la vie et à l'Échelle multidimensionnelle de soutien social perçu ont été administrés. Les données ont été analysées à l'aide de tests du khi carré et de la régression logistique.

Résultats : Plus de la moitié des participants étaient insatisfaits de leur vie. Les femmes âgées, actives et éduquées faisaient état d'un niveau de satisfaction plus élevé que les autres.

Conclusion : Les effets positifs significatifs du soutien social perçu et du taux d'activité physique indiquaient que l'interaction sociale peut jouer un rôle aussi essentiel que l'activité physique pour le bien-être des personnes âgées. De ce fait, ces qualités devraient être activement encouragées parmi les personnes âgées en République islamique d'Iran. 


$$
\begin{aligned}
& \text { درجة الرضا عن الحياة والعو امل المساهمة في تحقيق ذلك في صفوف السكان الأكبر سنا من غير المقيمين في مؤسسات الرعاية في تبريز، } \\
& \text { جمهورية إيران الإسلامية } \\
& \text { أكبر زين الحاجلو، مهستى عليز اده، محمد صاحبي حق، أصغر محمد بور اصل، حسين مطلبي } \\
& \text { الخلاصة } \\
& \text { الخلفية: مع النمو المتزايد للفئات السكانية الأكبر سنا، بات موضوع عافية المسنين يمثل هدفا مها لكل من السياسات الاقتصادية والسياسات } \\
& \text { الصحية. } \\
& \text { الأهداف: استقصت هذه الدر اسة مستويات الرضا عن الحياة في صفوف الأشخاص الأكبر سنا الذين يعيشون في المنزل، والعوامل المؤثرة عليها. }
\end{aligned}
$$

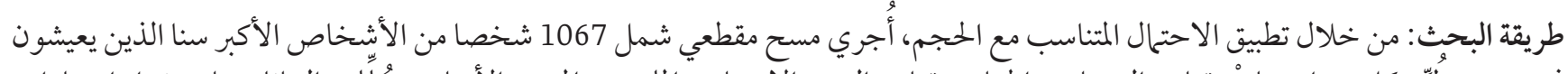

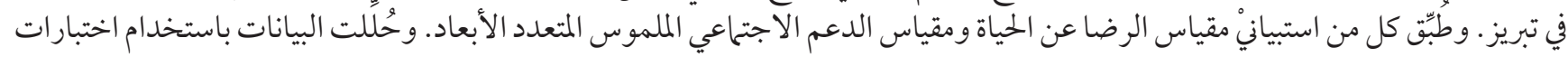

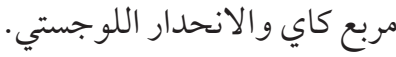

$$
\begin{aligned}
& \text { النتائج: أبدى أكثر من نصف المشار كين عدم رضاهم عن حياتهم. بينما أبدى الأشخاص الأكبر سنا من الإناث، و المتعلمين، والأكثر نشاطا رضا } \\
& \text { أكثر من سواهم. النئ. }
\end{aligned}
$$

\section{References}

1. Ataei SH. Changing global patterns of health and illness: a demographic transition and epidemiological transition. Medical History. 2012;4:11-24.

2. 10 facts on ageing and the life course. Geneva: World Health Organization; (http://www.who.int/features/factfiles/ageing/ageing_facts/en/, accessed 12 July 2016).

3. World population ageing. New York: United Nations Department of Economic and Social Affairs, Population Division; 2015 (ST/ ESA/SER.A/390; https://www.un.org/en/development/desa/population/publications/pdf/ageing/WPA2015_Report.pdf, accessed 29 April 2019).

4. Detailed results of the general population and housing census. Tehran: Statistical Center of Iran; 2012.

5. $\quad$ Mirzaie M. Factors affecting the elderly self-perceived health status. Iranian J Ageing. 2008;3(2);547-55.

6. Imani A, Dastgiri S, Azizi Zeinalhajlou A. Population aging and burden of diseases. Depiction of Health. 2015;6(2):54-61.

7. Pison G. Population ageing will be faster in the south than in the north. Population and Societies. 2009;457:1-4.

8. Country implementation profiles. New York: United Nations, ICPD; 2012.

9. Ardelt M. Wisdom and life satisfaction in old age. J Gerontol B: Psychol Sci Soc Sci. 1997;52:15-27. PMID:9008672

10. Inglehart R. Culture shift in advanced industrial society. Princeton, New Jersey: Princeton University Press; 1990.

11. Deiner E, Suh E, Lucas RE, Smith HL. Subjective well-being: three decades of progress. Psychological Bull. 1999;125;276-302.

12. Faraji T, Khademiyan T. A study on the effect of life satisfaction on the social delight. Quarterly of Sociological Studies of Youth. 2013;4(10);87-102.

13. Pavot W, Diener E. The Satisfaction with Life Scale and the emerging construct of life satisfaction. J Positive Psychol 2008;3:13752

14. Swami V, Chamorro-Premuzic T, Sinniah D, Maniam T, Kannan K. General health mediates the relationship between loneliness, life satisfaction and depression. Soc Psychiatry Psychiatr Epidemiol. 2007;42:161-6. doi:10.1007/s00127-006-0140-5

15. Ng ST, Tey NP, Asadullah MN. What matters for life satisfaction among the oldest-old? Evidence from China. PLoS ONE. 2017;12(2):1-16. https://doi.org/10.1371/journal.pone.o171799.

16. Kousheshi M, Khosravi A, Alizadeh M, Torkashvand M, Aghaei N. Population ageing in Iran: socio-economic, demographic and health characteristics of the elderly. Tehran: UNFPA and University of Tehran; 2014 (https://iran.unfpa.org/sites/default/files/ pub-pdf/Population\%20Ageing\%20in\%20I.\%20R.\%20Iran_2.pdf, accessed 14 April 2019).

17. Lavrakas PJ. Encyclopedia of survey research methods. Thousand Oaks, California: SAGE Publications; 2008.

18. Sheikhi M, Houman HA, Ahadi Allameh H, Sepah Mansour M. [Psychometric properties of the Satisfaction with Life Scale (SWLS)]. J Modern Industrial Organization Psychology 2010;1:17-25 (in Farsi).

19. Bayani AA, Koocheky AM, Goodarzi H. The reliability and validity of the satisfaction with life scale. J Iranian Psychologists 2007;3;259-60 (in Farsi).. 
20. Zimet GD, Dahlem NW, Zimet SG, Farley GK. The Multidimensional Scale of Perceived Social Support. J Person Assess. 1988;52;30-41. http://dx.doi.org/10.1207/s15327752jpa5201_2

21. Stanley M, Beck J, Zebb B. Psychometric properties of the MSPSS in older adults. Aging Ment Health. 1998;2:186-93.

22. Emaminaeini M, Bakhtiyari M, Hatami H, Khodakarim S, Sahaf R. Depression and perceived social support in the elderly. Iranian J Ageing. 2017;12(2):192-207. http://dx.doi.org/10.21859/sija-1202192

23. Abeles RP, Gift H, Ory MG. Aging and quality of life, 1st ed. New York: Springer; 1994.

24. Borg C, Hallberg IR, Blomqvist K. Life satisfaction among older people with reduced self $\square$ care capacity: the relationship to social, health and financial aspects. J Clin Nurs. 2006;15;607-18. doi:10.1111/j.1365-2702.2006.01375.x

25. Beygzadeh Z, Rezaei A, Khalouei Y. [The relationship between social support and life satisfaction with happiness among home-dwelling older adults in Shiraz]. Iranian J Ageing 2015;10;1-10 (in Farsi).

26. Maddah SB. [The status of social and leisure time activities in the elderly residing in Tehran and Sweden[. Iranian J Ageing 2008;3;597-606 (in Farsi).

27. Heinrich LM, Gullone E. The clinical significance of loneliness: a literature review. Clin Psychol Rev. 2006;26;695-718. doi:10.1016/j.cpr.2006.04.002

28. Koochaki G, Hojjati H, Sanagoo A. [The relationship between loneliness and life satisfaction of the elderly in Gorgan and Gonabad cities]. J Research Development in Nursing \& Midwifery. 2012;9;61-68 (in Farsi).

29. Adams GA, King LA, King D W. Relationships of job and family involvement, family social support, and work-family conflict with job and life satisfaction. J Applied Psychol. 1996;1;411-20.

30. Tamannayeefar MR, Mansoori Nik A. [The prediction of life satisfaction based personality factors, social support and spiritual well-being]. J Psychol. 2013;8;67-80 (in Farsi).

31. McCamish-Svensson C, Samuelsson G, Hagberg B, Svensson T, Dehlin O. Social relationships and health as predictors of life satisfaction in advanced old age: results from a Swedish longitudinal study. Int J Aging Hum Dev. 1999;48:301-24. doi:10.2190/ GXoK-565H-08FB-XF5G

32. Ho S, Woo J, Lau J, Chan S, Yuen Y, Chan Y. Life satisfaction and associated factors in older Hong Kong Chinese. J Am Geriatr Soc. 1995;43:252-5. PMID:7884112 